\title{
Land use evaluation and scenario analysis towards sustainable planning on the Loess Plateau in China-case study in a small catchment
}

\author{
Liding Chen ${ }^{\mathrm{a}, *}$, Ingmar Messing ${ }^{\mathrm{b}}$, Shurong Zhang $^{\mathrm{a}}$, \\ Bojie $\mathrm{Fu}^{\mathrm{a}}$, Stig Ledin ${ }^{\mathrm{b}}$ \\ a Department of Systems Ecology, Research Center for Eco-Environmental Sciences, Chinese Academy of \\ Sciences, Beijing 100085, China \\ ${ }^{\mathrm{b}}$ Department of Soil Sciences, Swedish University of Agricultural Sciences, Box 7014, SE-750 07 Uppsala, \\ Sweden
}

\begin{abstract}
The Loess Plateau has been suffering from serious soil erosion for a long time, which originated in a population growth about 2000 years ago. After then, the rapid increase in human activity has led to more areas became used for grain production. Original vegetation has been destroyed and soil erosion has become more and more serious. Most research works indicate that the soil erosion on the Loess Plateau is mainly induced by irrational land use structure and low vegetation coverage. Controlling soil erosion is a significant factor in making a sustainable land use planning for the Loess Plateau. In this study, a procedure towards such a planning is presented, based on results from a research project in a small catchment on the Loess Plateau. A land suitability evaluation for rain-fed agriculture based on biophysical parameters, and a comparison between land suitability and current land use, were first carried out. Some potential land use scenarios, based on surveys on biophysical and socio-economic parameters in the catchment, and plans by the authorities, were proposed for further evaluation of their effects on soil erosion, economic feasibility and social acceptance. The scenarios were tested by (i) simulation modeling, to show the differences in erosion, and (ii) from studies on the influence of the scenarios on farmers' economy and their response. The results indicated that the following land use scenario was acceptable: all land with deep soil and slopes smaller than $15^{\circ}$ is used for agriculture cropland, possibly combined with biological conservation measures, such as mulching combined with improved fallow, and all land with steeper slopes than $15^{\circ}$ is used for other purposes (orchards and other cash trees, woodland, shrubland, grassland). A great reduction of on-farm income, however, would be induced on the short term by such a scenario. Local farmers will find it difficult to accept it unless financial support from external sources is
\end{abstract}

* Corresponding author. Tel.: +86-10-62943840; fax: +86-10-62943840.

E-mail addresses: liding@mail.rcees.ac.cn, chenliding@sohu.com (L. Chen). 
available. On the long term, the scenario will be promising for both economic income improvement and soil erosion control since some production will be obtained from the conversion of cropland into orchards/cash trees (preferably on slopes $15-25^{\circ}$ ). Thus the land use modification should be carried out gradually. On the short term (5 year), it is suggested that cropland on steeper slopes than $25^{\circ}$ is returned to woodland/shrubland/grassland while also fruit trees are planted on slopes $15-25^{\circ}$. Within 10 years, cropland with slopes steeper than $15^{\circ}$ is suggested to be converted into orchard/ woodland/shrubland/grassland.

(C) 2003 Elsevier B.V. All rights reserved.

Keywords: Land use evaluation; Soil erosion; Scenario; Sustainable land use planning; Loess Plateau; China

\section{Introduction}

The Loess Plateau in China has been suffering from serious soil erosion for a long time, beginning about 2000 years ago as population grew (COSTLOP-CAS, 1991). With human activity increase, larger areas were used for grain production and soil erosion was becoming more and more serious. Furthermore, the highly variable rainfall resulted in temporal irregularity in land productivity, which made increasing areas of steep slope lands to be reclaimed for agricultural use. Surface soil loss in most hilly areas of the Loess Plateau reaches at present approximately 5000-10000 $\mathrm{Mg} \mathrm{km}^{-2}$ year $^{-1}$, which results in much nutrient loss and land degradation (BREST-CAS, 1992; Chen and Luk, 1989; Fu and Chen, 2000). Because of this, the Loess Plateau has received much attention from the Chinese government, as well as many international organisations (Yang and Yu, 1992; Lu et al., 1997; Wu and Yang, 1998). Many research studies indicate that soil erosion on the Loess Plateau is mainly induced by irrational land use and low vegetation coverage $(\mathrm{Fu}$, 1989; Fu and Gulinck, 1994; Jiang, 1997). Since the local farmers have limited access to the market, their principal income comes from the on-farm activities, such as growing agricultural crops. Basically, the Loess Plateau is an area where present land use cannot be sustained in the future. Planning aiming at a sustainable use of land is required.

In the procedure towards sustainable land use planning, there are many factors affecting the selection of land use scenarios. Among them, calculating of rates of soil erosion of different land use scenarios, and the impact of the scenarios on current farmers' income and response are crucial factors. Soil erosion as a result of different scenarios can be calculated using computer modeling. Even with optimum scenarios as calculated from modeling studies, current farmers' income and the response of the farmers on the scenarios determine their feasibility. Conventional land suitability evaluation often focuses on the suitability of land for different land use types, while overlooking the farmers' needs and response. Accordingly, proposed scenarios will often fail to be implemented properly due to that the requirements and perceptions of the local farmers was not really met (Stocking, 1996). Thus, a sustainable land use planning has to take into account as well biophysical suitability, as economic feasibility and social acceptability by the farmers of potential land use scenarios.

The objective of this article is to present a procedure towards sustainable land use planning in which the natural eco-environmental conditions, economic conditions and 
local farmers' acceptance and participation were considered. The study was carried out in a small catchment on the Loess Plateau in China, within the frames of a research project with the title "A participatory approach for soil and water conservation planning, integrating soil erosion modeling and land evaluation, to improve the sustainability of land use on the Loess Plateau in northern ChinaEROCHINA" (Ritsema, 2003). Other contributions from this project are found in this Special Issue.

\section{Study area and methods}

\subsection{The study area}

Danangou catchment is located in An'sai county, Yan'an area, Shaanxi Province in the northern part of the Loess Plateau $\left(36^{\circ} 54^{\prime}-36^{\circ} 56^{\prime} \mathrm{N}\right.$ and $\left.109^{\circ} 16^{\prime}-109^{\circ} 18^{\prime} \mathrm{E}\right)$, covering an area of $3.5 \mathrm{~km}^{2}$ (Fig. 1). The study area belongs to the loess hilly area where soil erosion rates are higher than that in the southern part of the Loess Plateau. Due to severe soil erosion, the ground surface has been incised strongly by rill and gully erosion. Mean annual precipitation is $522 \mathrm{~mm}(1956-1990)$, the maximum annual precipitation $958 \mathrm{~mm}$ (1964) and the minimum precipitation $297 \mathrm{~mm}$ (1974) based on An'sai station's meteorological measurements. Around $75 \%$ of the precipitation occurs during summer

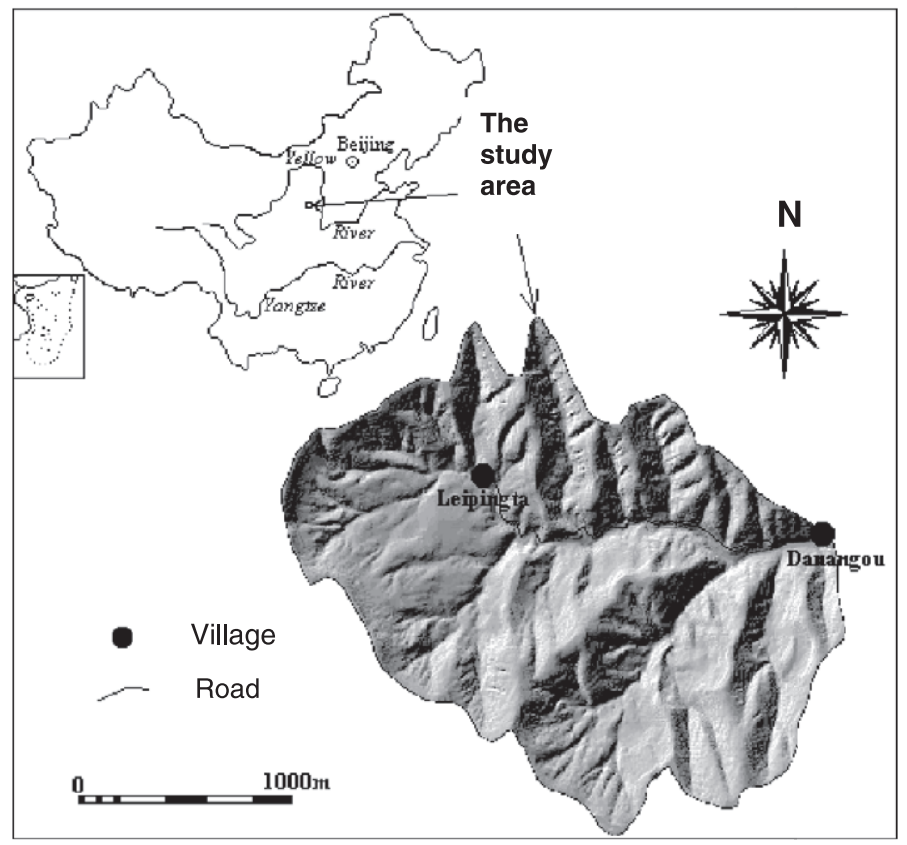

Fig. 1. Location of the study area. 
(June to September) and the annual variation rate is up to $74.5 \%$. There is very little runoff during the dry season (winter) but a high run-off during the rainy season (summer). Annual average temperature is $9{ }^{\circ} \mathrm{C}$, and monthly averages $-8{ }^{\circ} \mathrm{C}$ in January and +22 ${ }^{\circ} \mathrm{C}$ in July. The soil in the study area has been developed from loess, and is characterised by a loose structure and high erodibility. Based on the Soil Map of the World (FAOUnesco, 1974), the soils in this part of the Loess Plateau, orientated in a southwest/ northeast belt, are classified as Calcic Cambisols. On catchment scale, several classes of soils were identified (Messing et al., 2003a). Land uses in the area comprise slope cropland, terrace cropland, orchard, shrubland, woodland, road, residential land and sparse wild grassland. Common crops cultivated are millet (Panicum miliaceum), maize (Zea mays L.), sorghum (Sorghum spp.), beans (Vigna angularis Wight.), potato (Solanum tuberosum L.) and buckwheat (Avena spp.) (Chen et al., 2001). Little natural vegetation can be observed and most of the area is covered by secondary vegetation under human influence.

There are two villages in the study area, called Danangou and Leipingta (Fig. 1). Leipingta village is situated in the upper part with 85 inhabitants in 15 families, and Danangou village is located at the outlet of the catchment with 105 inhabitants in 23 families (1998). The residential areas for local farmers are usually dispersed on gentle hillslopes and cannot be delineated on the land use map with an individual polygon. Apart from many small tracks spotted in field, there is only one road connecting Leipingta and Danangou villages.

\subsection{Current land use mapping}

The mapping of the current land use is crucial as reference to relate back to in comparison with any potential land use scenarios. A 2-day land use reconnaissance survey was carried out, by which a general understanding of current land use types in the study area was reached. The land use within the study area was classified into eight groups: slope cropland, terrace cropland, check-dam cropland (flat land behind a dam, which has been filled up with silt deposits and normally used for agricultural cropping), dense woodland (coverage higher than 60\%), sparse woodland (coverage $30-60 \%$ ), shrubland, orchard and sparse wild grassland (little human management involved). Then, a detailed land use survey and mapping based on a topo-map of 1:10,000 was carried out in May 1998 and updated in September 1998. This map was digitized for further analysis by using GIS. In the present study, a simplified map is used (Fig. 2).

\subsection{Land parameter maps for suitability evaluation}

A land suitability evaluation along the guidelines for a framework by FAO (1976) was carried out based on some critical parameters, which determine the suitability of the land for agricultural cropland. The land parameters soil type and slope gradient were selected as basic parameters for land evaluation (Messing et al., 2003b). In the scenario analyses described under Section 2.4, additionally, the land parameters land form and slope aspect were integrated. 


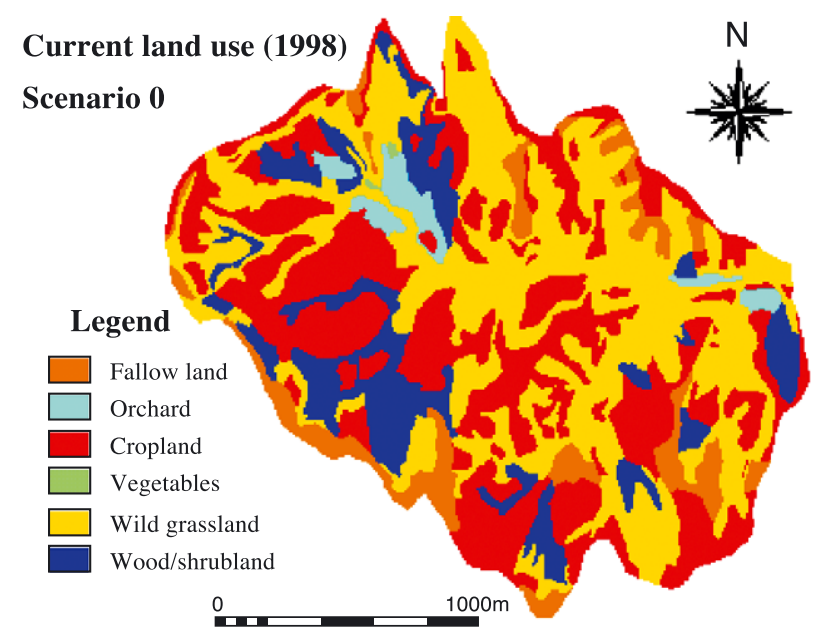

Fig. 2. Current land use map of the study area.

For each land parameter, a rating map was prepared based on a topo-map of the scale 1:10,000. A simplified soil map was used for this land evaluation considering the small differences between sub-loessial soil units. It was divided into the following groups: yellow loess soil (typical loess), reddish loess soil (loess with more clay), alluvial soil (soils behind check-dams), weathered bedrock and bedrock (Messing et al., 2003a; Wang et al., 2003). The slope gradient and slope aspect maps were derived from a Digital Elevation Model. Slope gradient was classified into five domains: $0-3^{\circ}, 3-8^{\circ}, 8-15^{\circ}, 15-25^{\circ}$ and $>25^{\circ}$ in accordance with the potential

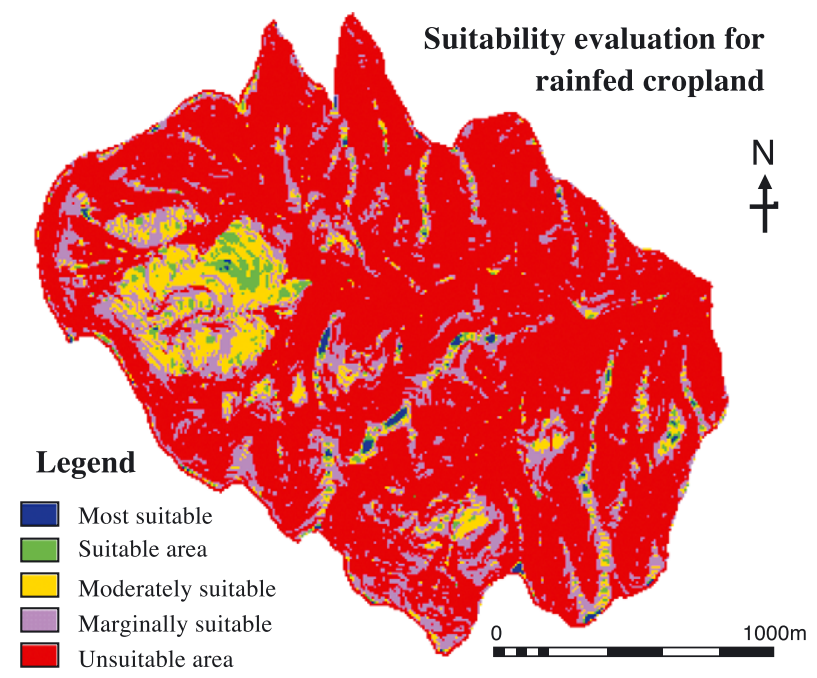

Fig. 3. Suitability map for rain-fed cropland. 
national policy on converting slope land into other uses in the future. Slope aspect was classified into eight groups: $0-45^{\circ}, 45-90^{\circ}, 90-135^{\circ}, 135-180^{\circ}, 180-225^{\circ}$, $225-270^{\circ}, 270-315^{\circ}$ and $315-360^{\circ}$. A landform map was delineated, classified into two groups: above gully edge (land on hilltops, where a gentle to moderate slope is often found) and below gully edge (land other than hilltops, where all slope steepness can be found). GIS was employed to delineate out the basic land units, by combining the rating maps, that was used for land suitability evaluation and scenario analyses.

\subsection{Land suitability and scenario analyses}

Suitability mapping for rain-fed agricultural cropland was based on critical land parameters and the requirements for cropping (Messing et al., 2003b). A suitability map for rain-fed cropland (Fig. 3) was prepared by attributing the basic land evaluation unit map with the criteria in Table 1.

Preliminary land use scenarios were derived by taking into account: (i) the current land use (Fig. 2), (ii) the land suitability for agricultural cropland (Fig. 3), (iii) other results from the biophysical resource inventory (Messing et al., 2003b), (iv) the local farmer's needs and perception as found in participatory approach (PA) studies in the two villages (Hoang Fagerström et al., 2003a,b), (v) preliminary planning from researchers and authorities (Hoang Fagerström et al., 2003a,b; personal communication). A soil erosion simulation model (LISEM) was used (Hessel et al., 2003) by which a comparison of soil erosion rates and volumes of the preliminary land use scenarios was made. In one of the PA studies, current land productivity and consumption in the study area was investigated as well as the influence of the proposed scenarios on farm incomes. The results of the preliminary scenarios modeling and PA studies were presented to the local farmers in village meetings (Hoang Fagerström et al., 2003b).

After taking into consideration the farmers' response to the preliminary scenarios in the village meetings, the scenarios were slightly modified. Four land use scenarios were proposed for check on soil erosion rates, and to be basic documents for sustainable planning in the catchment.

Scenario 0 was based on the land use distribution at the time of the study (current land use) (Fig. 2).

Table 1

Criteria for land suitability map for rain-fed cropland/fallow (from S1 to S5, the suitability ranges from high to low)

\begin{tabular}{|c|c|c|c|c|c|c|c|}
\hline \multicolumn{3}{|c|}{ Land suitability } & \multicolumn{5}{|c|}{ Slope degree classes } \\
\hline & & & $<3^{\circ}$ & $3-8^{\circ}$ & $8-15^{\circ}$ & $15-25^{\circ}$ & $>25^{\circ}$ \\
\hline \multirow[t]{5}{*}{ Soil classes } & 1 & Yellow loess and $>1200 \mathrm{~m}$ altitude & $\mathrm{S} 1$ & $\mathrm{~S} 2$ & S3 & S4 & S5 \\
\hline & 2 & Yellow loess $<1200 \mathrm{~m}$ altitude/alluvial & $\mathrm{S} 2$ & $\mathrm{~S} 3$ & S4 & S5 & S5 \\
\hline & 3 & Red loess & S3 & $\mathrm{S} 3$ & S4 & S5 & S5 \\
\hline & 4 & Weathered bedrock & S4 & $\mathrm{S} 4$ & S4 & S5 & S5 \\
\hline & 5 & Bedrock & S5 & S5 & S5 & S5 & S5 \\
\hline
\end{tabular}


Table 2

Definition of land use scenarios

\begin{tabular}{|c|c|c|c|c|c|c|c|c|}
\hline & Alluvial soils & Loessial s & oils and all & Ivial soils ( & $\left.>15^{\circ}\right)$ & & & Weathered \\
\hline & $0-15^{\circ}$ & $0-15^{\circ}$ & $15-20^{\circ}$ & $20-25^{\circ}$ & $>25^{\circ}$ & & & All \\
\hline & & & & & Above & Below gully & edge & \\
\hline & & & & & & $\begin{array}{l}\text { North- } \\
\text { facing }\end{array}$ & $\begin{array}{l}\text { South- } \\
\text { facing }\end{array}$ & \\
\hline Scenario 1 & $\begin{array}{l}\text { Vegetables/ } \\
\text { crops }\end{array}$ & Cropland & Cropland & Cropland & $\begin{array}{l}\text { Woodland/ } \\
\text { Shrubland }\end{array}$ & $\begin{array}{l}\text { Woodland/ } \\
\text { Shrubland }\end{array}$ & $\begin{array}{l}\text { Wild } \\
\text { grassland }\end{array}$ & $\begin{array}{l}\text { Wild } \\
\text { grassland }\end{array}$ \\
\hline Scenario 2 & $\begin{array}{l}\text { Vegetables/ } \\
\text { crops }\end{array}$ & Cropland & Cropland & $\begin{array}{l}\text { Orchard/ } \\
\text { cash tree }\end{array}$ & $\begin{array}{l}\text { Woodland/ } \\
\text { Shrub }\end{array}$ & $\begin{array}{l}\text { Woodland/ } \\
\text { Shrub }\end{array}$ & $\begin{array}{l}\text { Wild } \\
\text { grassland }\end{array}$ & $\begin{array}{l}\text { Wild } \\
\text { grassland }\end{array}$ \\
\hline Scenario 3 & $\begin{array}{l}\text { Vegetables/ } \\
\text { crops }\end{array}$ & Cropland & $\begin{array}{l}\text { Orchard/ } \\
\text { cash tree }\end{array}$ & $\begin{array}{l}\text { Orchard/ } \\
\text { cash tree }\end{array}$ & $\begin{array}{l}\text { Woodland/ } \\
\text { Shrub }\end{array}$ & $\begin{array}{l}\text { Woodland/ } \\
\text { Shrub }\end{array}$ & $\begin{array}{l}\text { Wild } \\
\text { grassland }\end{array}$ & $\begin{array}{l}\text { Wild } \\
\text { grassland }\end{array}$ \\
\hline
\end{tabular}

Scenario 1 was based on a redistribution of land use so that agricultural cropland is found only on loessial soils with slopes $<25^{\circ}$. Land with slopes $>25^{\circ}$ and land at all slope degrees with shallow soils (weathered bedrock and bedrock) are converted into other uses (woodland/shrubland/grassland).

Scenario 2 was based on a redistribution of land use so that agricultural cropland is found only on loessial soils with slopes $<20^{\circ}$. Land with slopes $20-25^{\circ}$ is converted to

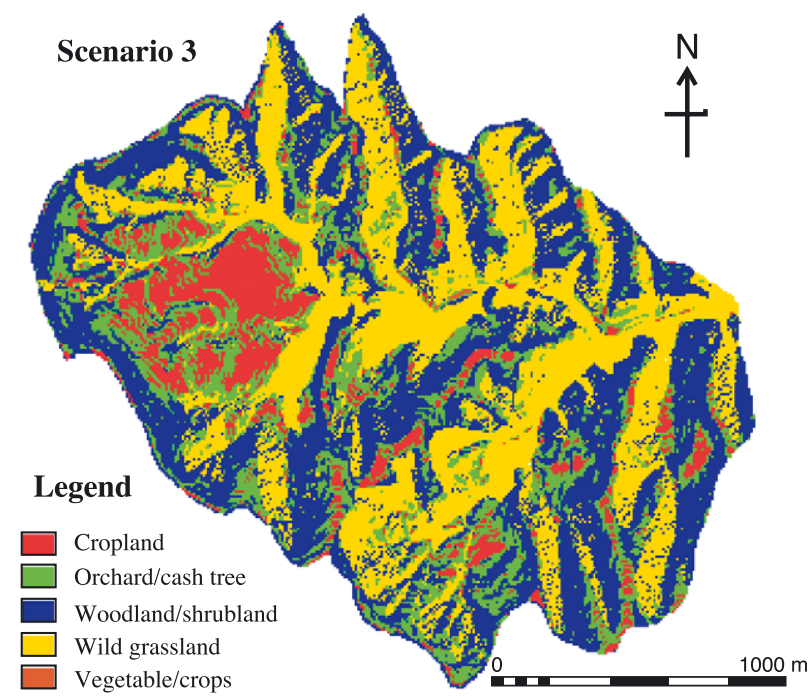

Fig. 4. Land use scenario 3. The land with orchard/cash tree (green) is in scenario 1 replaced by cropland, and in scenario 2 by orchard/cash tree in the higher portions and cropland in the lower portions, all other land units being equal to scenario 3 . 
orchard/cash trees and the land with slopes $>25^{\circ}$ and all land with shallow soils are converted into other uses (woodland/shrubland/grassland).

Scenario 3 was based on a redistribution of land use so that agricultural cropland is found only on loessial soils with slopes $<15^{\circ}$. Land with slopes $15-25^{\circ}$ is converted to orchard/cash trees and the land with slopes $>25^{\circ}$ and all land with shallow soils are converted into other uses (woodland/shrubland/grassland).

As for the scenarios 1-3 (Table 2, Fig. 4), much income from on-farm activities would be reduced on a short term due to a decrease in cropland area. How to provide adequate food for the local farmers would be a practical and economical issue faced by the local governments. Therefore, plantations of orchards/cash trees (combined with contour ridges and water harvesting) in the land with $15-25^{\circ}$ slopes were proposed which was assumed to give income on the long term (5-10 years).

For each of the scenarios, two systems of conservation measures for increasing crop productivity and reducing soil erosion using local resources were suggested:

(a) Biological measures: such as mulching on cropland and improved fallow (fallow planted by crop species which could be used for mulching and fodder to animals).

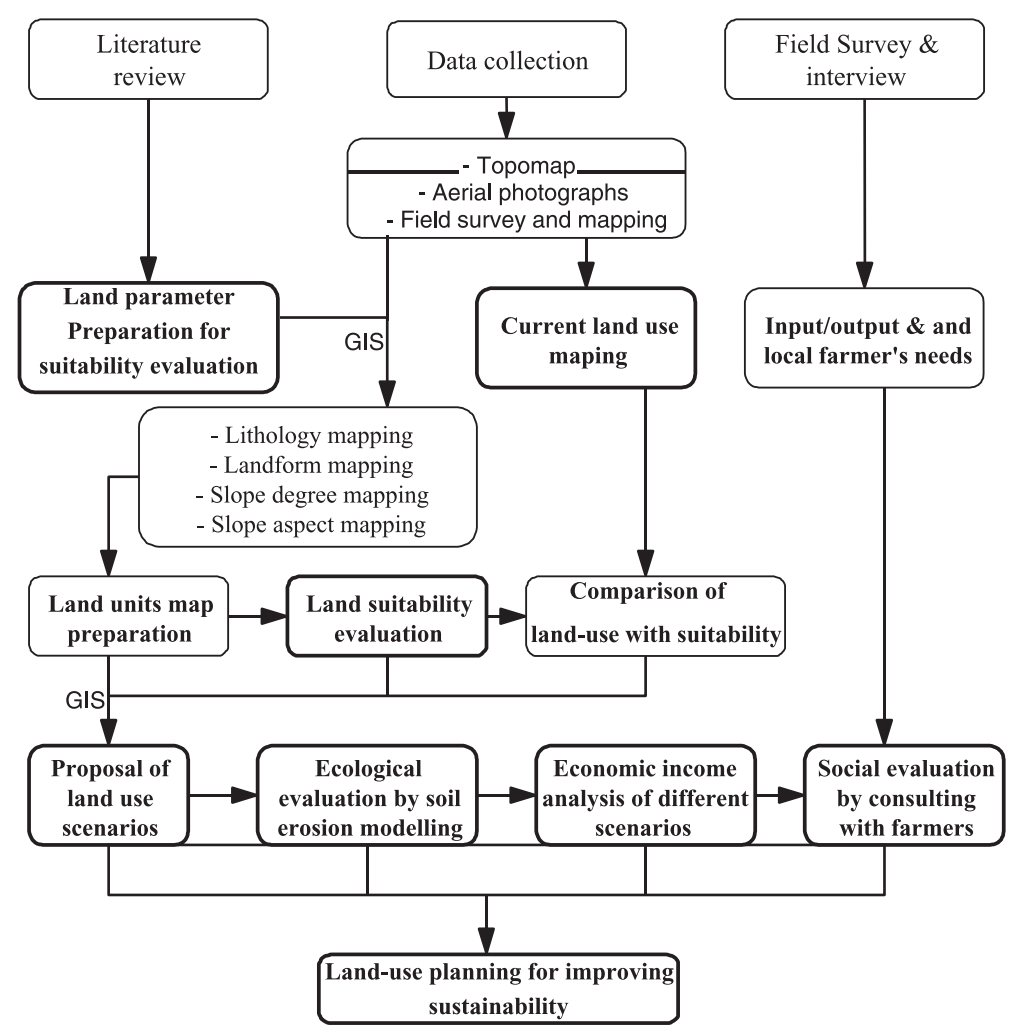

Fig. 5. Flow chart for the process outlined in this article. 
Table 3

Statistics of suitability for rain-fed cropland (from S1 to S5 the suitability ranges from high to low)

\begin{tabular}{lllllll}
\hline Suitability class & S1 & S2 & S3 & S4 & S5 & total \\
\hline Area (ha) & 1.4 & 5.6 & 25.2 & 61.9 & 255.6 & 347.9 \\
Portion of study area (\%) & 0.4 & 1.6 & 7.2 & 17.7 & 73.1 & 100 \\
\hline
\end{tabular}

(b) Mechanical measures: such as contour ridges (more or less permanent earth embankments) on cropland.

The whole procedure is summarised in Fig. 5.

\section{Results and discussion}

\subsection{Ecological evaluation}

The suitability map for rain-fed cropland (Fig. 3) indicates that about $10 \%$ of the study area was rated in the three highest suitability classes (S1, S2, S3), and about $90 \%$ found in the two lowest classes (S4, S5) (Table 3). About 44\% of the study area was currently used as cropland (Table 3; scenario 0), i.e. much higher than the suitable area for rain-fed cropland (10\%) (S1, S2, S3). The current pattern thus was unfavourable particularly from the point of view of soil erosion control in the area.

The area percentage of different land use types for different scenarios is shown in Table 4. From the results of soil erosion modeling derived by Hessel et al. (2003), it was found that the current land use distribution with improved measures (biological and mechanical), i.e. scenario 1 , gave a $10 \%$ reduction on total soil loss, compared with the current land use (scenario 0), the latter having a simulated total soil loss of 2830 ton at the occasion studied. The scenario 3 reduced soil erosion in the catchment $60 \%$, even without the measures, compared with scenario 0 . Improved measures had a smaller influence on scenario 3, only 5\% reduction in total soil loss (compared with the $10 \%$ in the case of scenario 0 ). The total soil loss for the other two scenarios was intermediate between scenario 0 and scenario 3 . This indicates

Table 4

Area distribution of different land use types of the scenarios

\begin{tabular}{lrrrrrrrr}
\hline Land use types & \multicolumn{3}{c}{ Scenario 0 } & \multicolumn{3}{c}{ Scenario 1 } & \multicolumn{3}{c}{ Scenario 2 } & \multicolumn{3}{c}{ Scenario 3 } \\
\cline { 2 - 10 } & Area (ha) & \multicolumn{1}{c}{ \% } & Area (ha) & \multicolumn{1}{c}{ \% } & Area (ha) & \% & Area (ha) & $\%$ \\
\hline Cropland & 154.3 & 44.1 & 95.4 & 27.3 & 63.3 & 18.1 & 35.3 & 10.1 \\
Orchard/cash tree & 8.4 & 2.4 & 8.4 & 2.4 & 40.6 & 11.6 & 68.5 & 19.6 \\
Woodland/shrubland & 45.1 & 12.9 & 128.7 & 36.8 & 128.7 & 36.8 & 128.7 & 36.8 \\
Wild grassland & 141.5 & 40.5 & 116.8 & 33.4 & 116.8 & 33.4 & 116.8 & 33.4 \\
Vegetable/crops & 0.4 & 0.1 & 0.4 & 0.1 & 0.4 & 0.1 & 0.4 & 0.1 \\
Total & 349.7 & 100.0 & 349.7 & 100.0 & 349.7 & 100.0 & 349.7 & 100.0 \\
\hline
\end{tabular}


Table 5

Average yield and unit price of different crops in different types of land

\begin{tabular}{lccccc}
\hline $\begin{array}{l}\text { Crop } \\
\text { types }\end{array}$ & $\begin{array}{l}\text { Steep slope } \\
\text { area }(\mathrm{kg} / \mathrm{ha})\end{array}$ & $\begin{array}{c}\text { Gentle slope } \\
\text { area }(\mathrm{kg} / \mathrm{ha})\end{array}$ & $\begin{array}{c}\text { Terrace } \\
(\mathrm{kg} / \mathrm{ha})\end{array}$ & $\begin{array}{c}\text { Alluvial } \\
\text { plain }(\mathrm{kg} / \mathrm{ha})\end{array}$ & $\begin{array}{c}\text { Unit price } \\
\mathrm{Y} / \mathrm{kg}^{\mathrm{a}}\end{array}$ \\
\hline Maize & 3000 & 4500 & 6000 & 6500 & 0.8 \\
Pear & 670 & 800 & 950 & 1000 & 1.2 \\
Foxtail & 1000 & 1200 & 1500 & 1680 & 1.2 \\
Potato & 7500 & 9000 & 12,000 & 12,500 & 0.6 \\
Apple & 7500 & 10,000 & - & - & 1.0 \\
Vegetable & & & & 12,000 & 0.8 \\
\hline
\end{tabular}

${ }^{\mathrm{a}}$ The price is based on market survey and state guided price.

that the proposed land use scenarios 3,2 and 1 are better compared with the current land use scenario 0, and mulching improvement was slightly better than contour ridges.

Table 6

Productivity (yield) of different land use scenarios for different crops $(\mathrm{kg})^{1}$

\begin{tabular}{|c|c|c|c|c|c|c|c|c|}
\hline \multicolumn{2}{|c|}{ Scenario } & \multirow[t]{2}{*}{ Maize } & \multirow[t]{2}{*}{ Pear millet } & \multirow{2}{*}{$\begin{array}{l}\text { Foxtail } \\
\text { millet }\end{array}$} & \multirow[t]{2}{*}{ Potato } & \multicolumn{2}{|l|}{ Apple } & \multirow[t]{2}{*}{ Vegetable } \\
\hline & & & & & & Short term ${ }^{4}$ & Long term ${ }^{5}$ & \\
\hline \multirow[t]{4}{*}{0} & Area (ha) & 38.58 & 46.29 & 38.58 & 30.86 & 8.35 & 80.35 & 0.40 \\
\hline & Scenario 0 & 128,963 & 32,391 & 40,340 & 242,040 & 62,625 & 62,625 & 4,800 \\
\hline & Scenario $0 \mathrm{a}$ & 117,356 & 29,476 & 36,709 & 220,256 & 68,888 & 68,888 & 4,800 \\
\hline & Scenario $0 \mathrm{~b}$ & 123,804 & 31,095 & 38,726 & 232,358 & 68,888 & 68,888 & 4,800 \\
\hline \multirow[t]{4}{*}{1} & Area (ha) & 23.86 & 28.64 & 23.86 & 19.09 & 8.35 & 8.35 & 0.40 \\
\hline & Scenario 1 & 84,825 & 20,562 & 25,628 & 153,765 & 62,625 & 62,625 & 4,800 \\
\hline & Scenario $1 \mathrm{a}^{3}$ & 77,191 & 18,712 & 23,321 & 139,926 & 68,888 & 68,888 & 4,800 \\
\hline & Scenario $1 b^{2}$ & 81,432 & 19,740 & 24,602 & 147,614 & 68,888 & 68,888 & 4,800 \\
\hline \multirow[t]{4}{*}{2} & Area (ha) & 15.83 & 18.99 & 15.83 & 12.66 & 40.60 & & 0.40 \\
\hline & Scenario 2 & 60,713 & 11,750 & 17,590 & 131,925 & 62,625 & 304,500 & 4,800 \\
\hline & Scenario $2 \mathrm{a}^{3}$ & 55,248 & 12,831 & 16,007 & 96,041 & 68,888 & 334,950 & 4,800 \\
\hline & Scenario $2 b^{2}$ & 58,284 & 13,536 & 16,886 & 101,318 & 68,888 & 334,950 & 4,800 \\
\hline \multirow[t]{4}{*}{3} & Area (ha) & 8.83 & 10.59 & 8.83 & 7.06 & 68.50 & 68.50 & 0.40 \\
\hline & Scenario 3 & 39,713 & 8472 & 10,590 & 63,540 & 62,625 & 513,750 & 4,800 \\
\hline & Scenario $3 \mathrm{a}^{3}$ & 36,138 & 7710 & 9637 & 57,821 & 68,888 & 565,125 & 4,800 \\
\hline & Scenario $3 b^{2}$ & 38,124 & 8,133 & 10,166 & 60,998 & 68,888 & 565,125 & 4,800 \\
\hline
\end{tabular}

${ }^{1}$ The productivity was derived by supposing that the area percentage of maize, pear millet, foxtail millet and potato was having the following proportions, respectively: $25 \%, 30 \%, 25 \%$ and $20 \%$ and by using the formula $P=\Sigma Y_{i} A_{i}$. Here, $Y_{i}, A_{i}$ are, respectively the unit yield and area of different grade lands.

${ }^{2}$ With mulching used, the area of land used for cropland will be reduced by about $30 \%$ and the yield of crop will be hopefully be increased by 30\% (Xue, 1994; Wu and Yang, 1998; Jiang, 1997).

${ }^{3}$ With contour ridges used in cropland, the land used for cropland will decrease by $20 \%$ and the yield of crops will increase by about 20\% compared to that in the gentle slope areas (Xue, 1994; Wu and Yang, 1998; Jiang, 1997). With ridge and mulching improvements used in orchard, the yields will be hopefully increase by about $10 \%$ compared to that of the current situation.

${ }^{4}$ Short term means that the period from planting of fruit seedling to the date of producing economic benefit.

${ }^{5}$ From a long-term point of view, the subsidence for returning cropland into orchard/cash trees/woodland/ shrubland/grassland will gradually be reduced and stopped when full economic benefits are obtained from orchards and other cash trees. 


\subsection{Economic evaluation}

The original data from PA studies on the impact of the scenarios on farm incomes (Hoang Fagerström et al., 2003a,b) have here been adapted to suit the purpose of the present study. The average crop yield of different land (Table 5) was used for calculating land productivity and evaluating economic income of different scenarios (Table 6). On a short term, the scenarios 1, 2 and 3 give lower total income than the current land use, scenario 0 (Table 7). Compared with the current situation, the total income of local farmers would not be sufficient to support their daily life, even if some subsidence from the central government would be available for converting the slope croplands into other uses. However, the economic income on a long term could be increased by $50-100 \%$ when the seedlings from fruit trees and other cash trees are grown up and give production (Table 7).

\subsection{Social evaluation}

The farmers' acceptance to the land use scenarios will determine their feasibility. Due to the decrease in cropland area (Table 4), the proposed land use scenarios whether with or without improvements (such as biological or mechanical measures) will give reduction in productivity on a short term (Table 7). From a long term perspective, however, on-farm income are supposed to increase for the scenarios 2 and 3, if benefits from orchards and other cash trees are included and intensification of cropland management by improved

Table 7

Economic income of different land use scenarios for different crop types (RMB)

\begin{tabular}{|c|c|c|c|c|c|c|c|c|}
\hline \multirow{2}{*}{\multicolumn{2}{|c|}{$\begin{array}{l}\text { Income } \\
\text { items } \\
\text { Scenario }\end{array}$}} & \multirow{3}{*}{$\begin{array}{l}\begin{array}{l}\text { Income } \\
\text { from } \\
\text { cropland }\end{array} \\
335,671\end{array}$} & \multicolumn{2}{|c|}{$\begin{array}{l}\text { Income } \\
\text { from orchard }\end{array}$} & \multirow{2}{*}{$\begin{array}{l}\text { Income } \\
\text { from } \\
\text { vegetable }\end{array}$} & \multirow{2}{*}{$\begin{array}{l}\text { Subsidence } \\
\text { due to cropland } \\
\text { reduction }\end{array}$} & \multicolumn{2}{|l|}{$\begin{array}{l}\text { Total } \\
\text { income }\end{array}$} \\
\hline & & & \multirow{2}{*}{$\begin{array}{l}\text { Short term }{ }^{1} \\
62,625\end{array}$} & \multirow{2}{*}{$\begin{array}{l}\text { Long term }{ }^{2} \\
62,625\end{array}$} & & & \multirow{2}{*}{$\begin{array}{l}\text { Short term } \\
\end{array}$} & \multirow{2}{*}{$\begin{array}{l}\text { Long term }^{2} \\
62,625\end{array}$} \\
\hline 0 & Scenario 0 & & & & 3,840 & No & & \\
\hline & Scenario $0 \mathrm{a}$ & 305,461 & 68,888 & 68,888 & 3,840 & No & 378,188 & 68,888 \\
\hline & Scenario $0 \mathrm{~b}$ & 322.244 & 68,888 & 68,888 & 3,840 & No & 394,971 & 68,888 \\
\hline \multirow[t]{3}{*}{1} & Scenario 1 & 215.547 & 62,625 & 62,625 & 3,840 & 88,275 & 370,287 & 62,625 \\
\hline & Scenario 1a & 196,147 & 68,888 & 68,888 & 3,840 & 88,275 & 357,150 & 68,888 \\
\hline & Scenario $1 b$ & 206,925 & 68,888 & 68,888 & 3,840 & 88,275 & 367,927 & 68,888 \\
\hline \multirow[t]{3}{*}{2} & Scenario 2 & 149,922 & 62,625 & 304,500 & 3,840 & 136,500 & 352,887 & 594,762 \\
\hline & Scenario $2 \mathrm{a}$ & 136,429 & 68,888 & 334,950 & 3,840 & 136,500 & 345,657 & 611,719 \\
\hline & Scenario $2 b$ & 143,925 & 68,888 & 334,950 & 3,840 & 136,500 & 353,153 & 619,215 \\
\hline \multirow[t]{3}{*}{3} & Scenario 3 & 92,768 & 62,625 & 513,750 & 3,840 & 178,500 & 337,733 & 788,858 \\
\hline & Scenario $3 \mathrm{a}$ & 84,419 & 68,888 & 565,125 & 3,840 & 178,500 & 335,647 & 831,884 \\
\hline & Scenario $3 b$ & 89,058 & 68,888 & 565,125 & 3,840 & 178,500 & 340,286 & 836,523 \\
\hline
\end{tabular}

${ }^{1}$ Short term means that the period from planting of fruit seedling to the date of producing economic benefit. Within this period, some financial support from the central government is necessary, that will be used to support the local farmers to return slope cropland to orchard/cash trees/woodland/shrubland/grassland.

${ }^{2}$ From a long-term point of view, the subsidence for returning cropland into orchard/cash trees/woodland/ shrubland/grassland will gradually be reduced and stopped when full economic benefits are obtained from orchards and other cash trees. 
measures bring about higher yields. In the PA studies the acceptance of different scenarios among the local farmers was evaluated (Hoang Fagerström et al., 2003b). It was found that biological measures, such as mulching combined with improved fallow, were favoured measures to improve land use structure, especially by the women. These measures can increase the production from cropland and at the same time give grass to the livestock. Mechanical measures, such as constructing dams and terraces, were less favoured by the women, since their construction and maintenance needs much more money and labour. Some of the men, on the other hand, had a tendency to favour dams and terraces. Contour ridges in cropland were not a favorite choice, since they were supposed to demand more work to build and maintain than the expected increase in yield they would provide with. Nevertheless, whether these improvements could be employed properly greatly depended on any financial support from the outside since it is hard for the local farmers to afford these kinds of projects. An interview with the local government showed that this greatly depended on the economic situation of the whole country scenarios. During the conversion of slope cropland into other uses, financial support from the government and international organisations is crucial. However, a proposed subsidy of $1500 \mathrm{RMB}$ per ha for converting slope cropland into other uses is not enough for the local farmers to sustain their lives.

Further consideration on the impact of scenarios on farmers' acceptance and economy is given in Hoang Fagerström et al. (2003b).

\section{Conclusions}

Based on the results in this study, the land use scenario 3: concentrating cropland to loessial soils with slopes $<15^{\circ}$, possibly combined with the biological conservation measures such as mulching/improved fallow, and converting the rest of the land to orchards/cash trees/woodland/shrubland/grassland, was a good choice from ecological/ biophysical point of view. However, this scenario will induce a great reduction in on-farm income on a short term, which makes it difficult to be accepted by the local farmers if no financial and other support from external side is available. One of the most important things to consider is whether the local farmers can get support from outside when making a sustainable planning in the study area. If a great deal of support was available, the land use scenario 3 with biological measures was suggested since it is favourable on soil erosion control and accepted by the local farmers. The land use modification needs to be carried out gradually. Within a short term (about 0-5 years), cropland is suggested to be concentrated on loessial soils with slopes $<25^{\circ}$, and slopes $>25^{\circ}$ converted into woodland/shrubland/grassland at the same time as orchard/cash trees is started to be planted on parts of the slopes $<25^{\circ}$. On medium term (about 5-10 years), the cropland located at slopes $>20^{\circ}$ can be fully converted into orchard/cash trees $\left(20-25^{\circ}\right)$ and woodland/shrubland/grassland $\left(>25^{\circ}\right)$. After 10 years, the cropland at slopes $>15^{\circ}$ is suggested to have changed into the other uses (orchard/cash trees on $15-25^{\circ}$ land, and woodland/shrubland/grassland on $>25^{\circ}$ land). The results of LISEM modeling on the impact on erosion and water runoff with these proposed scenarios are presented in Hessel et al. (2003). 


\section{Acknowledgements}

This article is the result of an EU financed project "A participatory approach for soil and water conservation planning, integrating soil erosion modeling and land evaluation, to improve the sustainability of land use on the Loess Plateau in Northern China EROCHINA, (IC18-CT97-0158)". It is also supported by Chinese Academy of Sciences (Kzcx2-310-03) and partially funded by China National Natural Science Foundation (90102018/49725101). The authors would like to thank Dr. M.H.H. Fagerström and Dr. R. Hessel for their suggestions in the establishment of scenarios, and Dr. J. Wang, Mr. Y. Qiu, Mr. M. Carlsson, Ms. C. Olsson, Mr. C. Andersson, Mr. M. Xu, Mr. Z. Wen and other members of the EROCHINA project for their cooperation during field surveys.

\section{References}

Bureau of Resource, Environmental Science and Technology, Chinese Academy of Sciences (BREST-CAS), Stig, 1992. Development and Comprehensive Treatment on Small Catchment in Loess Plateau China Science and Technology Literature Press, Beijing. (In Chinese).

Chen, Y.Z., Luk, S.H., 1989. Sediment sources and recent changes in the sediment load of Yellow River, China. In: Rindwanich, S. (Ed.), Land Conservation for Future GenerationsProceedings of the 5th International Soil Erosion Conference, Ministry of Agriculture, Bangkok, Thailand, 18-29 Jan. 1988 Department of Land Development, Bangkok, pp. 313-323.

Chen, L.D., Wang, J., Fu, B.J., Qiu, Y., 2001. Land use change in a small catchment of northern Loess Plateau China. Agriculture, Ecosystems \& Environment 86 (2), $163-172$.

Comprehensive Survey Team on Loess Plateau of Chinese Academy of Sciences (COSTLOP-CAS), Y., 1991. The Natural Environmental Characteristics and Evolvement China Science and Technology Press, Beijing. (In Chinese).

FAO, Y., 1976. A framework for land evaluation. Soils Bulletin, vol. 32. Food and Agricultural Organization of the United Nations, Rome, $72 \mathrm{pp}$.

FAO-Unesco, Y., 1974. Soil Map of the World (1:5000000) Food and Agricultural Organisation of the United Nations, Unesco, Paris.

Fu, B.J., 1989. Soil erosion and its control in the Loess Plateau of China. Soil Use and Management 5, 76-82.

Fu, B.J., Chen, L.D., 2000. Agricultural landscape spatial pattern analysis in the semi-arid area of the Loess Plateau. China Journal of Arid Environment 44, 291-303.

Fu, B.J., Gulinck, H., 1994. Land evaluation in an area of severe erosion: the Loess Plateau of China. Land Degradation and Rehabilitation 5, 33-40.

Hessel, R., Messing, I., Chen, L.D., Ritsema, C.J., Stolte, J., 2003. Soil erosion simulations of land use scenarios for a small Loess Plateau catchment. Catena 54, 289-302. (doi:10.1016/S0341-8162(03)00070-5)

Hoang Fagerström, M.H., Messing, I., Wen, Z.M., 2003a. A participatory approach for integrated conservation planning in a small catchment in Loess Plateau, China: Part I. Approach and methods. Catena 54, 255-269. (doi:10.1016/S0341-8162(03)00068-7)

Hoang Fagerström, M.H., Messing, I., Wen, Z.M., Trouwborst, K.O., Xu, M.X., Zhang, X.P., Olsson, C., Andersson, C., 2003b. A participatory approach for integrated conservation planning in a small catchment in Loess Plateau, China: Part II. Analysis and findings. Catena 54, 271-288. (doi:10.1016/S03418162(03)00069-9)

Jiang, D. (Ed.), 1997. Soil Erosion and Control Models in the Loess Plateau. China Hydroelectricity Press, Beijing (In Chinese).

Lu, Z., Liang, Y., Liu, G., 1997. Ecological Agriculture in Loess Plateau, China Shaanxi Science and Technology Press, Xi'an (In Chinese).

Messing, I., Chen, L.D., Hessel, R., 2003. Soil conditions in a small catchment on the Loess Plateau in China. Catena 54, 45-58. (doi:10.1016/S0341-8162(03)00056-0) 
Messing, I., Hoang Fagerström, M.H., Chen, L.D., Fu, B.J., 2003. Criteria for land suitability evaluation in a small catchment on the Loess Plateau in China. Catena 54, 215-234. (doi:10.1016/S0341-8162(03)00066-3)

Ritsema, C.J., 2003. Soil erosion and participatory land use planning on the Loess Plateau in China. Catena 54, 1-5. (doi:10.1016/S0341-8162(03)00052-3)

Stocking, M., 1996. Land management for sustainable development: farmers' participation. In: Uitto, J.I., Ono, A. (Eds.), Population, Land management, and Environmental Change. The United Nations University, Tokyo.

Wang, J., Fu, B.J., Qui, Y., Chen, L.D., 2003. Analysis on soil nutrient characteristics for sustainable land use in Danangou catchment of the Loess Plateau, China. Catena 54, 17-29. (doi:10.1016/S0341-8162(03)00054-7)

Wu, Y., Yang, W. (Eds.), 1998. Forest and Grassland Vegetation Construction and its Sustainable Development in Loess Plateau. Science Press, Beijing (In Chinese).

Xue, Z., 1994. A new model of slope cropland. In: Wang, Z., Liu, L. (Eds.), Comprehensive Treatment Technology and Study on Soil Erosion in Wuding River Basin. Shaanxi Science and Technology Press, Xi'an, pp. 205-208

Yang, W., Yu, C., 1992. Regional Treatment and Evaluation in Loess Plateau Science Press, Beijing (In Chinese). 